\title{
Expanding the role of tachykinins in the neuroendocrine control of reproduction
}

\author{
Chrysanthi Fergani and Víctor M Navarro \\ Department of Medicine, Division of Endocrinology, Diabetes, and Hypertension, Brigham and Women's Hospital \\ and Harvard Medical School, Boston, Massachusetts, USA
}

Correspondence should be addressed to V M Navarro; Email: vnavarro@bwh.harvard.edu

\begin{abstract}
Reproductive function is driven by the hormonal interplay between the gonads and brain-pituitary axis. Gonadotropin-releasing hormone $(\mathrm{GnRH})$ is released in a pulsatile manner, which is critical for the attainment and maintenance of fertility; however, GnRH neurons lack the ability to directly respond to most regulatory factors, and a hierarchical upstream neuronal network governs its secretion. We and others proposed a model in which Kiss1 neurons in the arcuate nucleus (ARC), called as KNDy neurons, release kisspeptin (a potent GnRH secretagogue) in a pulsatile manner to drive GnRH pulses under the coordinated autosynaptic action of its cotransmitters, the tachykinin neurokinin B (NKB, stimulatory) and dynorphin (inhibitory). Numerous genetic and pharmacological studies support this model; however, additional regulatory mechanisms (upstream of KNDy neurons) and alternative pathways of GnRH secretion (kisspeptin independent) exist, but remain ill defined. In this aspect, attention to other members of the tachykinin family, namely substance P (SP) and neurokinin A (NKA), has recently been rekindled. Even though there are still major gaps in our knowledge about the functional significance of these systems, substantial evidence, as discussed below, is placing tachykinin signaling as an important pathway for the awakening of the reproductive axis and the onset of puberty to physiological GnRH secretion and maintenance of fertility in adulthood.

Reproduction (2017) 153 R1-R14
\end{abstract}

\section{Introduction}

Successful production of offspring is indispensable to perpetuate species. As such, reproduction is under the control of a complex regulatory network, which involves the hypothalamic-pituitary-gonadal ( $\mathrm{H}-\mathrm{P}-\mathrm{G})$ axis. Gonadotropin-releasing hormone $(\mathrm{GnRH})$ neurons, located in the hypothalamus, are a major component of the $\mathrm{H}-\mathrm{P}-\mathrm{G}$ axis and the ultimate regulators of reproductive function, including sexual behavior (Moenter et al. 2003, Herbison et al. 2008, Herbison 2016). Importantly, GnRH release is pulsatile, and even though $\mathrm{GnRH}$ neurons may display autonomous activity (spontaneous bursts), these do not seem to correlate with $\mathrm{GnRH} / \mathrm{LH}$ pulses in vivo (reviewed in Navarro 2012). Furthermore, GnRH neurons lack the ability to sense most factors that influence reproductive function, such as endogenous signals (e.g. sex steroid hormones (Radovick et al. 2012, Hrabovszky \& Liposits 2013, Roa 2013)) as well as environmental cues (e.g. stressors (Dobson et al. 2003)). Thus, a large body of research is now focusing on the discovery of higher hierarchy circuits and their efficacy in stimulating $\mathrm{GnRH}$ secretion into the hypophyseal portal vessels, thereby enabling gonadotropin (luteinizing hormone (LH) and follicle-stimulating hormone $(\mathrm{FSH})$ ) secretion from the anterior pituitary into the peripheral circulation. From then on, $\mathrm{LH}$ and $\mathrm{FSH}$ reach the gonads to stimulate gametogenesis and sex steroid production. In turn, sex steroids exert positive and negative feedback effects on pituitary and hypothalamic target cells (Herbison 1998), completing the $\mathrm{H}-\mathrm{P}-\mathrm{G}$ axis. In this respect, over the past 10 years, several upstream neurophenotypes have been implicated in stimulatory and/or inhibitory regulation of GnRH secretion.

The path was initially paved with the discovery that loss-of-function mutations in several neuroendocrine genes, including KISS1 and its receptor, KISS1R (Table 1), have been described to cause hypogonadotropic hypogonadism in humans (de Roux et al. 2003, Seminara et al. 2003, Chan et al. 2011, Topaloglu et al. 2012) due to a central deficit that leads to absent $\mathrm{GnRH} / \mathrm{LH}$ pulses, highlighting the importance of these neural cues in $\mathrm{GnRH}$ release. Further anatomical and functional studies provided unequivocal evidence that kisspeptins, encoded by the Kiss 1 gene (Table 1), are the most potent secretagogues of $\mathrm{GnRH}$ in all mammals studied to date (Oakley et al. 2009). A number of studies by our lab and others suggest that Kiss1 neurons, which contact $\mathrm{GnRH}$ neurons directly, receive profuse central and peripheral 
Table 1 Protein and gene nomenclature for kisspeptin, tachykinins and their receptors, in human and rodent species.

\begin{tabular}{lcccccc}
\hline & \multicolumn{2}{c}{ Gene encoding ligand } & & \multicolumn{2}{c}{ Gene encoding receptor } \\
\cline { 2 - 3 } Ligand & Human & Rodent & & Highest affinity receptor & Human & Rodent \\
\hline Kisspeptin & KISS1 & Kiss1 & & Kisspeptin 1 receptor (GPR54) & KISS1R & Kiss1r \\
Substance P & TAC1 & Tac1 & & Neurokinin receptor 1 (NK1R) & TACR1 & Tacr1 \\
Neurokinin A & TAC1 & Tac1 & & Neurokinin receptor 2 (NK2R) & TACR2 & Tacr2 \\
Neurokinin B & TAC3 & Tac2 & & Neurokinin receptor 3 (NK3R) & TACR3 & Tacr3 \\
\hline
\end{tabular}

regulatory inputs that modulate kisspeptin secretion for the initiation of puberty and the maintenance of fertility in adulthood (Seminara et al. 2003, Pinilla et al. 2012). Importantly, Kiss1 neurons also play a critical role in conveying information about the sex steroid milieu to GnRH neurons (Navarro et al. 2004, Gill et al. 2010). However, kisspeptin action on GnRH neurons is necessary but not sufficient for the proper activation of $\mathrm{GnRH}$ neurons (Leon et al. 2016).

The development of newer, more potent and less expensive tools to screen genome sequences of affected patients is revealing a growing number of factors that appear critical for the timing of puberty onset and maintenance of fertility by regulating kisspeptin and/ or $\mathrm{GnRH} / \mathrm{LH}$ release. Within this constellation of neuroendocrine systems is the one that comprises tachykinin neurokinin B (NKB) and its receptor (NK3R) encoded by TAC3 and TACR3 in humans respectively (Table 1). This system has received substantial attention as the identification in 2009 of inactivating mutations in these genes are also associated with hypogonadotropic hypogonadism and lack of puberty onset (Topaloglu et al. 2009, 2012, Young et al. 2010, Yang et al. 2012), resembling the phenotype of KISS1/KISS1R-null patients. Moreover, the systemic administration of an NK3R antagonist (ESN364) in OVX ewes, castrated or cycling nonhuman primates as well as healthy men and women (Fraser et al. 2015, 2016) show a partial inhibition of the reproductive axis. Indeed, numerous follow-up animal studies confirmed that NKB is a critical stimulatory input to the $\mathrm{GnRH}$ network in various species (Navarro 2013, Goodman et al. 2014) although, interestingly, this stimulatory effect is not observed in healthy men (Narayanaswamy et al. 2016), probably due to their circulating sex steroid levels as discussed below. However, unlike kisspeptin deficiency, the phenotype of patients lacking NKB signaling is less severe as reversal cases have been documented, in which some patients recovered reproductive function and fertility after delayed puberty (Gianetti et al. 2010). A similar subfertile phenotype has been observed in genetically modified mouse models, where Tac2 and Tacr3 (encoding NKB and NK3R respectively, in rodents, Table 1), had been deleted from the genome (Steiner \& Navarro 2012, Yang et al. 2012, True et al. 2015). Therefore, it appears that the reversal phenotype in reproductive viability observed in human individuals with TAC3/TACR3 or rodents with Tac2/Tacr3 mutations may be due to compensation by other neuronal systems.
Interestingly, NKB is a member of the broader tachykinin family, which has the common C-terminal sequence of Phe-X-Gly-Leu-Met- $\mathrm{NH}_{2}$ (Maggio 1988). This family also includes substance $\mathrm{P}(\mathrm{SP})$, neurokinin A (NKA), neuropeptide $K$ (NPK) and neuropeptide $\gamma$ (NPy) (Otsuka \& Yoshioka 1993, Page 2005). The vast majority of research has focused on SP, NKA and NKB, which bind preferentially to the NK1R, NK2R and NK3R G-protein-coupled receptors respectively (Maggi 1995, Patacchini \& Maggi 2001, Saffroy et al. 2003).

Early studies documented a robust stimulatory action of $\mathrm{LH}$ release by SP in rats, rabbits and humans (Arisawa et al. 1990, Coiro et al. 1992, Kalra et al. 1992, Sahu \& Kalra 1992, Traczyk et al. 1992), and recent electrophysiological studies have described potent depolarizing effects of SP and NKA on ARC Kiss1 neurons in the mouse (de Croft et al. 2013) indicating that LH stimulation by these tachykinins involves, at least in part, a kisspeptin-dependent mechanism. Of note, this study showed that, in vitro, the activation of kisspeptin neurons by NKB was completely diminished only when all three neurokinin receptor (NKR) subtypeselective antagonists were concomitantly applied in the in vitro bath (de Croft et al. 2013). This is in line with studies carried out in vivo indicating that blockade of all 3 tachykinin receptors (but not each one of them individually) prevented the compensatory rise of LH after gonadectomy (GDX) in rats (Noritake et al. 2011). Therefore, considerable cross-reactivity exists between these receptor/ligand systems, and each one of these neuropeptides is capable of eliciting responses from all three neurokinin receptors (Cascieri et al. 1992, Gether et al. 1993, Beaujouan et al. 2000). In these studies, the affinities or EC50 values of each tachykinin for NK1R, NK2R and NK3R respectively were reported as follows: SP_2 nM, 2200 nM and 18,000 nM; NKA_16nM, $3 \mathrm{nM}$ and $1300 \mathrm{nM}$ and NKB_70 $\mathrm{nM}, 25 \mathrm{nM}$ and $4 \mathrm{nM}$ (Seabrook et al. 1995). These data suggest a likely interaction of NKA with NK1R as well as NK2R, and of NKB with all 3 receptors, at relatively low concentrations. Furthermore, it has been demonstrated in rats that pulsatile LH secretion was suppressed by central administration of CS-003, an antagonist for all three NKRs, whereas administration of each NKR subtypeselective antagonist alone had no effect (Noritake et al. 2011). In this respect, several pieces of evidence will be discussed below that provide unequivocal evidence that other members of the tachykinin family, namely SP and NKA, all encoded by the TAC1 or Tac1 gene (Table 1), 
in humans and rodents respectively (Lasaga \& Debeljuk 2011) are an important component of the integrated neuronal hypothalamic system that controls $\mathrm{GnRH} / \mathrm{LH}$ secretion in mammals.

\section{The current model for the GnRH pulse generator}

Kiss1 neurons are located primarily in two discrete hypothalamic nuclei: the arcuate nucleus (ARC) and the anteroventral periventricular nucleus (AVPV/PeN) in rodents (Clarkson et al. 2009) or the preoptic area in ruminants (Lehman et al. 2010), monkeys (Luque et al. 2011) and humans (Hrabovszky 2014). Compelling evidence suggests that Kiss1 neurons in the ARC mediate the negative feedback of sex steroids, and Kiss 1 expression is inhibited by estradiol $\left(E_{2}\right)$ and testosterone (T). By contrast, Kiss 1 expression in the AVPV/PeN, almost exclusive to the female brain, is upregulated by $E_{2}$ and mediates the positive feedback that leads to the femalespecific preovulatory $\mathrm{GnRH} / \mathrm{LH}$ surge (Navarro et al. 2004, Smith et al. 2005, Maeda et al. 2007). Substantial in vivo and in vitro evidence points to the importance of a population of neurons located in the ARC of the hypothalamus in playing the role of the $\mathrm{GnRH}$ pulse generator. The notion originated from studies carried out in the ovariectomized (OVX) rhesus monkey, in which $\mathrm{LH}$ secretion was abolished by selective lesioning of the ARC (Plant et al. 1978) and was further reinforced by findings that multiunit electrical activity (MUA) in the vicinity of ARC kiss1 neurons was tightly coupled LH pulses (Kawakami et al. 1982, Ohkura et al. 2009). In this context, Kiss1 neurons in the ARC coexpress dynorphin (inhibitory) and NKB (stimulatory) referred to as KNDy neurons (Cheng et al. 2010, Navarro 2012, Goodman et al. 2013), which have been proposed to act in a coordinated, reciprocal fashion to shape the pulsatile release of kisspeptin in the median eminence, which in turn induces corresponding intermittent GnRH discharges at this site (Keen et al. 2008). This has since been demonstrated in a variety of mammals including mice (Navarro et al. 2009), rats (Navarro et al. 2011a), sheep (Goodman et al. 2013), goats (Wakabayashi et al. 2010) and monkeys (Ramaswamy et al. 2010). In this model, NKB would stimulate kisspeptin release and dynorphin would then inhibit this release through autosynaptic loops, thus shaping a kisspeptin/GnRH/ LH pulse (Keen et al. 2008). This is supported by the anatomical findings that virtually all KNDy neurons express NK3R (Navarro et al. 2009, 2011b, Amstalden et al. 2010) and $>90 \%$ express kappa-opioid receptor (KOR; (Weems et al. 2016)). Furthermore, KNDy cells are interconnected with NKB fibers within the ARC forming a tightly regulated network (Rance \& Bruce 1994, Krajewski et al. 2010, Lehman et al. 2010). Indeed, a growing number of studies in multiple species from our lab and others support the ability of NKB, or the NKB receptor (NK3R) agonist senktide, to increase $\mathrm{LH}$ pulses
(Grachev et al. 2012, Navarro 2013, Goodman et al. 2014). This places the KNDy neurons as ideal candidates for the role of the GnRH pulse generator. However, more recently, several studies have provided evidence that other tachykinins, i.e., SP and NKA, merit further investigation as additional fundamental components of the current, KNDy-dominated, GnRH pulse generator model. Although no human mutations in the genes encoding SP and NKA (TAC1) or their receptors (TACR1 and TACR2 respectively; Table 1) have been correlated with reproductive disorders yet, both SP and NKA have been reported to stimulate the gonadotropic axis in several species (Arisawa et al. 1990, Kalra et al. 1992, Sahu \& Kalra 1992, Noritake et al. 2011, de Croft et al. 2013, Navarro et al. 2015) including men (Coiro et al. 1992). It is therefore plausible to speculate that these tachykinins are involved in the central regulation of $\mathrm{GnRH}$ release and may be additional elements to the $\mathrm{GnRH}$ pulse generator.

\section{Anatomical studies}

The topographical identification of tachykinin ligands and their receptors has provided important insight in to the potential mechanisms of action of these systems for the control of $\mathrm{GnRH} / \mathrm{LH}$ secretion. Several studies using in situ hybridization, immunohistochemistry and single-cell RT-PCR for the detection of mRNA and protein of tachykinins and their receptors, as well as their morphological relationship to Kiss1 and $\mathrm{GnRH}$ neurons, have been carried out to date. However, important information, especially regarding the localization of receptors, across a large number of species, is still lacking.

\section{Distribution of SP and NKA in the hypothalamus and anatomical relationship with Kiss1 and GnRH neurons}

Within the hypothalamus, the largest population of NKB immunoreactive cells has been detected in the ARC (and specifically in the middle to caudal aspects) with smaller numbers identified in the ME, POA, lateral septum, bed nucleus of the stria terminalis, amygdala and the paraventricular nucleus of rats, sheep and mice (Rance \& Young 1991, Goubillon et al. 2000, Navarro et al. 2009). The ARC population has received most attention, as in this nucleus, kisspeptin and NKB reside in the same cell (KNDy; (Goodman et al. 2007, Navarro et al. 2009)), whereas no instances of NKB and GnRH colocalization have been reported, although $\mathrm{GnRH}$ and NKB immunopositive fibers have been observed to interweave in the rat ME (Krajewski et al. 2005).

In mice, Tac1 mRNA (encoding SP and NKA) has been mapped out in the brain of female mice using in situ hybridization (Navarro et al. 2015). Within the hypothalamus, expression was found to be concentrated mainly in 2 regions: the ARC (especially the caudal aspect) 
and the ventromedial nucleus (VMN), in keeping with previous reports of SP immunoreactivity in rats, monkeys and humans (Ronnekleiv et al. 1984, Yamano et al. 1986, Harlan et al. 1989, Rance \& Young 1991, Tsuruo et al. 1991, Rance \& Bruce 1994, Borsay et al. 2014). Studies using immunohistochemical detection of SP also report a plethora of fibers that innervate the entire length of the ARC and the median eminence (ME) (Hrabovszky et al. 2013, Kalil et al. 2015, Fergani et al. 2016), which appear to surround the capillaries of the hypophyseal portal system indicating that SP may have the ability to act directly on the anterior pituitary (Kalil et al. 2015).

Interestingly, even though the Tac2 (gene encoding NKB; Table 1) is known to be coexpressed within Kiss1 in the ARC of various species, including humans (Goodman et al. 2007, Navarro et al. 2009, Hrabovszky 2014), the Tac1-positive neurons did not colocalize with Kiss1-positive neurons in the mouse (Navarro et al. 2015; Fig. 1). This is in agreement with equivalent investigations in the sheep Fergani et al. 2016), monkey (Kalil et al. 2015) and rat (Rance \& Bruce 1994) but contradict findings in the human that report that approximately $65 \%$ of SP neurons in the ARC coexpress kisspeptin (conversely, 30\% of Kiss1 neurons contain SP; (Hrabovszky et al. 2013)). The reason for this divergence is not known, however, it supports the notion for the existence of

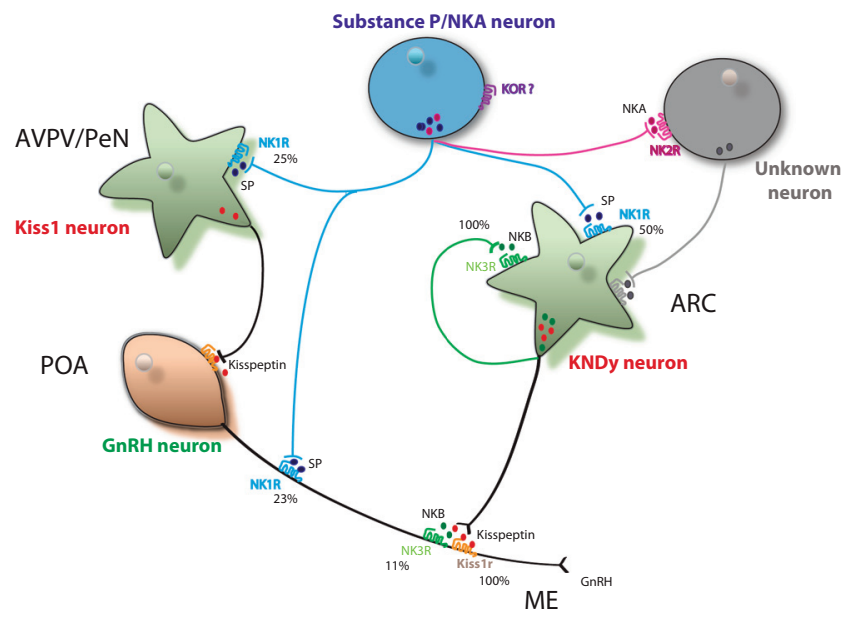

Figure 1 Schematic representation of a hypothalamic neuronal network comprising Kiss1 neurons, GnRH neurons and Tac1 neurons in the mouse. Percentage data depicting the co-expression of each receptor at each neuronal population as observed in studies carried out in mice using single-cell RT-PCR (Navarro et al. 2015). ARC Kiss1 neurons (KNDy neurons) are able to respond to NKB and half of them can also respond to SP. A subset of AVPV/PeN Kiss1 neurons also expresses the receptor for SP (NK1R) and a small fraction of them also express NKB receptor (NK3R). In addition, GnRH neurons, which respond primarily to kisspeptin, express SP and NKB receptors in small numbers. Finally, NKA must act on yet unknown intermediate neurons to stimulate kisspeptin release. Note: the location of the receptors in the cell (soma vs terminals) in this model, as well as the location of NKA-responsive neurons, is merely hypothetical. potential differences in the function of the tachykinin systems across species (Hrabovszky et al. 2013, Kalil et al. 2015, Navarro et al. 2015). Nonetheless, the population of Tac1 neurons in the ARC of the mouse (Navarro et al. 2015) and SP immunoreactive neurons and fibers in the monkey (Kalil et al. 2015) appeared to be in close contact with Kiss1 neurons and fibers (and $\mathrm{GnRH}$ fibers as shown in postmenopausal women (Hrabovszky et al. 2013)) in the ARC, presumably facilitating the interaction between all three neuronal populations. Immunohistochemical analysis of NKA fiber colocalization with kisspeptin or GnRH afferents merits future investigation. Of note, Tac1 mRNA was not detected in the AVPV/PeN of mice (Fig. 1) or the POA of sheep Fergani et al. 2016), respectively, the regions in which the second population of Kiss 1 neurons reside (Oakley et al. 2009); however, data from other species are non-existent.

\section{Distribution of NK1R and NK2R in the hypothalamus and anatomical relationship with Kiss1 and GnRH neurons}

Single-cell RT-PCR analysis of the expression of all 3 tachykinin receptors (Tacr1, Tacr2 and Tacr3 mRNA; Table 1) in Kiss1 (ARC and AVPV/PeN) and GnRH neurons showed that almost half $(\sim 49 \%)$ of Kiss1 neurons in the ARC and over one-fourth ( 27\%) of Kiss1 neurons in the AVPV/PeN express Tacr 1 mRNA, which is also present in a subset of $\mathrm{GnRH}$ neurons ( 23\%; (Navarro et al. 2015)). By contrast, in the sheep, NK1R protein was detected infrequently in kisspeptin neurons (approximately 6\% of kisspeptin neurones coexpressed NK1R) in the ARC, but not in Kisspeptin or GnRH cells in the POA Fergani et al. 2016) Tacr2, was absent from both populations of Kiss 1 neurons and $\mathrm{GnRH}$ neurons in mice (Navarro et al. 2015). Finally, Tacr3 was confirmed to be present in all (100\%) ARC Kiss 1 neurons but minimally present $(\sim 10 \%)$ in AVPV/ PeN Kiss1 neurons of mice, as has been previously described in various species (Navarro et al. 2009, 2015, Amstalden et al. 2010). Of note, Tacr3 mRNA was also detected in a small subset of $\mathrm{GnRH}$ neurons ( 11\%; (Navarro et al. 2015)) as has been previously been reported in the rat $(16 \%$ of $\mathrm{GnRH}$ somata contained NK3R immunostaining) (Krajewski et al. 2005) but not in the sheep (Amstalden et al. 2010, Ahn et al. 2015). In addition, extensive colocalization between GnRH axons with NK3R-positive fibers have been reported in the ME and organum vasculosum of the lamina terminalis of the rat (Krajewski et al. 2005), whereas $>70 \%$ GnRH neurones are contacted by NK3R presynaptic terminals in the sheep Ahn et al. 2015). Whether NK1R or NK2R is expressed in KNDy and/or GnRH neurons in other species is unknown.

Taken together, these anatomical data allow us to postulate that SP can regulate $\mathrm{GnRH}$ secretion not only 
indirectly by initial action on Kiss1 neurons but also directly by acting on GnRH neurons, although functional evidence for this pathway is lacking. Furthermore, the existence of axo-axonic or axo-dendritic synapses between SP and Kiss1 or GnRH axons remains to be elucidated. In the human, where SP and kisspeptin have been shown to colocalize, autocrine/paracrine actions of SP on KNDy neurons are also probable (Hrabovszky et al. 2013). Intriguingly, in the mouse, a subset of AVPV/PeN Kiss1 neurons are also receptive to SP actions (one-fourth of these cells contain NK1R), and it is well known that this population is involved in the generation of the GnRH/LH surge (Oakley et al. 2009). Therefore, a role for SP signaling in the shaping of the $\mathrm{GnRH}$ surge is likely, but remains unexplored. The action of NKA, on the other hand, remains largely unresolved because Tacr2 has been identified in neither Kiss 1 nor GnRH neurons, thus suggesting the presence of unidentified intermediate upstream neurons ((Navarro et al. 2015); Fig. 1).

\section{Sex steroid regulation of $S P$ and NKA}

All known cotransmitters present in ARC Kiss1 neurons (Kiss1, NKB and dynorphin) are inhibited by sex steroids as part of their hypothesized role in the negative feedback upon GnRH release (Gottsch et al. 2009, Navarro et al. 2009). This also appears to be true for SP and NKA, as Tac1-expressing neurons in the ARC and VMN of mice were downregulated by $\mathrm{OVX}$ and $\mathrm{E}_{2}$ treatment (Micevych et al. 1988, Navarro et al. 2015) and immunopositive SP protein in the ARC increased after gonadectomy (GND) in the male monkey (Kalil et al. 2015). Furthermore, this effect appeared to be specific for these areas of the brain (Navarro et al. 2015) and was not evident elsewhere. Similarly, SP mRNA increased in the hypothalamus of post- menopausal compared to pre-menopausal women (Rance \& Young 1991), and the content of SP in the ARC has been shown to increase after OVX in the rat (Tsuruo et al. 1987). The results of all these studies suggest that downregulation of SP and NKA in hypothalamic neurons may mediate, at least in part, the negative feedback action of gonadal steroids on gonadotropin secretion. Indeed, earlier studies have demonstrated that a substantial population of SP-immunoreactive cells located in the mediobasal hypothalamus of the rat are estrogen receptive $(26.1 \%$ in the $\operatorname{Arc}$ and $42.9 \%$ in the VMN) (Akesson \& Micevych 1988). Interestingly, immunohistochemical studies on human hypothalami have revealed that postmenopausal women have higher numbers of SP neurons and darker labeling than in agematched men (Hrabovszky et al. 2013). However, if this constitutes a sex difference in the expression of SP or it is a mere reflection of different levels of sex steroids remains to be elucidated. In this context, an earlier report documents greater SP immunoreactivity in the medial amygdala of male compared to female rats (Micevych et al. 1988), an area which is also known for a greater
Kiss 1 population of cells in males vs females (Stephens et al. 2016). However, the interaction between these two systems (SP and Kiss1 in the medial amygdala) has not yet been explored. Nonetheless, sex differences in the expression of SP or NKA require further characterization across multiple species.

\section{Regulation of LH release by tachykinins: sex steroid-dependent action}

\section{Neurokinin B}

Most studies carried out to date looking into the effect of tachykinins on reproductive function have focused on the role of NKB and less so on other members of the tachykinin family. Therefore, it is useful to compare findings from SP and NKA studies with those already carried out for NKB, as a synergistic action is highly probable. One thing that can be said about the stimulatory effect of NKB on LH release is that it is less robust than that of kisspeptin, and inhibitory actions or null effects on LH secretion have also been documented, depending on the species and the sex steroid levels (Sandoval-Guzman \& Rance 2004, Navarro et al. 2011a, Ruiz-Pino et al. 2012). For instance, NKB induced significantly stimulatory LH responses in adult female rats and mice under physiological levels of sex steroids, whereas only adult intact male mice (but not rats) displayed $\mathrm{LH}$ responses to the same challenge (Navarro et al. 2011b, Ruiz-Pino et al. 2012). By contrast, predominant inhibitory effects of the selective NK3R agonist, senktide, have been reported in rodents with null or low sex steroids levels (Sandoval-Guzman \& Rance 2004, Navarro et al. 2009, 2011b, 2015, Grachev et al. 2012), even though kisspeptins are known to stimulate gonadotropin secretion irrespective of the sex steroid milieu (Oakley et al. 2009). From a mechanistic point of view, the inhibitory action of NKB on $\mathrm{LH}$ release appears to be opioid mediated, as has been shown by the lack of LH inhibition by senktide in the presence of KOR agonist in rats (Kinsey-Jones et al. 2012). In accordance, extracellular recordings from KNDy neurons demonstrated that gonadal feedback (by both estrogen and dihydrotestosterone) attenuates the stimulatory effects of senktide on the firing rate of KNDy neurons while increasing the inhibitory effects of dynorphin by modulating the activation of NK3R and KOR (Ruka et al. 2016). Interestingly, in the sheep, NKB/NK3R signaling may also be important in the generation of the preovulatory $\mathrm{GnRH} / \mathrm{LH}$ surge. For example, intracerebroventricular (i.c.v.) microinjections of senktide, in this species, results in a surge-like elevation of $\mathrm{LH}$ during the follicular but not the luteal phase of the ovine estrous cycle (Billings et al. 2010, Porter et al. 2014), replicating a potential dual effect of NKB, dependent on sex steroid levels, as observed in rodents (Navarro et al. 2011a). 
These observations illustrate the complexity of the effects of NKB on the gonadotropic axis.

\section{Substance $P$}

To date, SP has largely been associated with processes unrelated to reproductive function, such as pain perception and inflammatory activity in the brain (De Felipe et al. 1998) as well as with psychiatric disorders (Ebner \& Singewald 2006). Even though SP was originally identified in the 1930s (Lasaga \& Debeljuk 2011), it is only now beginning to come in to the spotlight as a regulator of the reproductive axis. Few earlier studies aimed to investigate the effects of SP on the gonadotropic axis and report variable results (Table 2). These include peripheral (i.v.) administration of SP for 1 hour in normal men, which induced a robust discharge of LH (Coiro et al. 1992), and in OVX rats, i.c.v.-specific antiserum against SP (anti-SP) decreased plasma LH, whereas synthetic SP injected i.c.v. or i.v. into $\mathrm{OVX}+\mathrm{E}_{2}$ rats stimulated $\mathrm{LH}$ release by both routes of administration (Arisawa et al. 1990). Other studies conducted by Kalra and coworkers in the 90s (Kalra et al. 1992, Sahu \& Kalra 1992) report null or inhibitory effects in intact and GND males respectively, hinting at potential sex differences in response to SP (Table 2). Further studies conducted on intact and OVX rabbits report that although the stimulatory effect of SP on $\mathrm{LH}$ is sex steroid independent, in the absence of ovarian steroids, SP is stimulatory only during the rising phase of an LH pulse (Traczyk et al. 1992). Interest in SP has recently rekindled and studies in mice are pointing toward a clear stimulatory action on LH secretion, which appears to be independent of the sex steroid milieu (Table 2; (Navarro et al. 2015)). In this study, the activation of NK1R with the i.c.v. administration of an NK1R-specific agonist (GR73632) induced LH release in intact males, diestrous or OVX females and a 20-fold increase in OVX $+E_{2}$ females (Navarro et al. 2015). However, in rats that received the same agonist i.c.v., with the same dose, no alteration in LH levels was observed in either sex with intact gonads (Ruiz-Pino et al. 2015) indicating a potential species difference. This notion is also supported by pharmacological data from ovary-intact anestrous ewes and OVX and OVX $+\mathrm{E} 2$ goats demonstrating that much higher doses of SP are needed to stimulate $\mathrm{LH}$ secretion compared to those needed with NKB or senktide (Yamamura et al. 2015, Fergani et al. 2016).

In addition, a small body of literature has focused on the role of SP on the LH surge as well as sexual behavior. Intriguingly, a number of reports by Kerdelhué and coworkers, in humans, monkeys and rats have shown variable results. Initially, a study carried out in cycling rats investigated the effects of a subcutaneous injection of SP during proestrus, which led to a reduction of the LH surge amplitude (Duval et al. 1996). Furthermore, this inhibitory effect was reversed with the simultaneous administration of SP and an NK1 R antagonist (RP 67580) (Duval et al. 1996). However, further studies showed a

Table 2 Summary of results from in vivo studies investigating the effects of Substance P on LH secretion in various species.

\begin{tabular}{|c|c|c|c|c|c|c|c|}
\hline Species & Sex & Age & Drug & Gonadal status & Route & LH & Reference \\
\hline \multicolumn{8}{|c|}{ With the presence of sex steroids } \\
\hline Human & Male & Adult & SP peptide & Intact & i.v. for $1 \mathrm{~h}$ & Stimulation & Coiro et al. (1992) \\
\hline Rat & Female & Adult & SP peptide & $\mathrm{OVX}+\mathrm{E}_{2}$ & i.c.v. & Stimulation & Arisawa et al. (1990) \\
\hline Rat & Female & Adult & SP peptide & $\mathrm{OVX}+\mathrm{E}_{2}^{2}$ & i.v. & Stimulation & Arisawa et al. (1990) \\
\hline Rat & Male & Adult & SP peptide & Intact & i.c.v. & No effect & Kalra et al. (1992) \\
\hline Rabbit & Female & Adult & SP peptide & Intact & i.c.v. & Stimulation & Traczyk et al. (1992) \\
\hline Rabbit & Female & Adult & SP peptide & End of LH pulse & i.c.v. & No effect & Traczyk et al. (1992) \\
\hline Mouse & Male & Adult & GR73632 (NK1R-Agonist) & Intact & i.c.v. & Stimulation & Navarro et al. (2015) \\
\hline Mouse & Female & Adult & GR73632 (NK1R-Agonist) & $\mathrm{OVX}+\mathrm{E}_{2}$ & i.c.v. & Stimulation & Navarro et al. (2015) \\
\hline Rat & Female & Adult & GR73632 (NK1R-Agonist) & Intact & i.c.v. & No effect & Ruiz-Pino et al. (2015) \\
\hline Rat & Male & Adult & GR73632 (NK1R-Agonist) & Intact & i.c.v. & Stimulation & Ruiz-Pino et al. (2015) \\
\hline Sheep & Female & Adult & SP peptide & Intact (anestrous) & i.c.v. & Stimulation & Goodman et al. (2015) \\
\hline Goat & Female & Adult & GR73632 (NK1R-Agonist) & $\mathrm{OVX}+\mathrm{E}_{2}$ & i.v. & No effect & Yamamura et al. (2015) \\
\hline \multicolumn{8}{|c|}{ Without the presence of sex steroids } \\
\hline Rat & Female & Adult & Anti-SP peptide & OVX & i.c.v. & Inhibition & Arisawa et al. (1990) \\
\hline Rat & Female & Adult & Anti-SP peptide & OVX & i.v. & No effect & Arisawa et al. (1990) \\
\hline Rat & Male & Adult & SP peptide & Castrated & i.c.v. & Inhibition & Kalra et al. (1992) \\
\hline Rat & Female & Adult & SP peptide & OVX & i.c.v. & No effect & Sahu and Kalra (1992) \\
\hline Rat & Female & Adult & (Sar9,Met(O2)11)SP (NK1R-Agonist) & OVX & i.c.v. & No effect & Sahu and Kalra (1992) \\
\hline Rabbit & Female & Adult & SP peptide & OVX & i.c.v. & Stimulation & Traczyk et al. (1992) \\
\hline Mouse & Female & Adult & GR73632 (NK1R-Agonist) & OVX & i.c.v. & Stimulation & Navarro et al. (2015) \\
\hline Goat & Female & Adult & GR73632 (NK1R-Agonist) & OVX & i.v. & Stimulation & Yamamura et al. (2015) \\
\hline \multicolumn{8}{|c|}{ Prepubertally } \\
\hline Monkey & Male & Juvenile & SP peptide & $\begin{array}{l}\text { Castrated and } \\
\text { GnRH primed }\end{array}$ & Bolus i.v. & No effect & Kalil et al. (2015) \\
\hline Mouse & Female & Prepubertal & GR73632 (NK1R-Agonist) & Intact & i.c.v. & Stimulation & Simavli et al. (2015) \\
\hline Rat & Female & Prepubertal & GR73632 (NK1R-Agonist) & Intact & i.c.v. & Stimulation & Ruiz-Pino et al. (2015) \\
\hline Rat & Male & Prepubertal & GR73632 (NK1R-Agonist) & Intact & i.c.v. & Stimulation & Ruiz-Pino et al. (2015) \\
\hline
\end{tabular}

OVX, ovariectomized female; $\mathrm{OVX}+\mathrm{E}_{2}$, ovariectomized and estradiol treated female. 
divergence in results using the NK1R antagonist (RPR 100893) in OVX $+E_{2}$-treated vs intact cycling monkeys. In the first study, the NK1 R antagonist was administered in $\mathrm{OVX}+\mathrm{E}_{2}$-treated monkeys causing a $50 \%$ enhancement of the LH surge (Kerdelhue et al. 1997), supporting an inhibitory role of SP in the LH surge mechanism, similar to what was observed in the rat (Duval et al. 1996). By contrast, the same antagonist administered during the ascending phase of plasma estradiol concentrations (prior to LH surge onset of cycling monkeys), resulted in a reduction in both the amplitude $(41 \%)$ and the duration of the preovulatory LH surge (Kerdelhue et al. 2000), providing evidence for a stimulatory role of SP in this model. Additional detailed analysis of changes in plasma SP concentration during the periovulatory period in women showed higher SP values during the day of the LH peak, the day of the descending phase and the day after the descending phase compared to all other stages in the menstrual cycle (Kerdelhue et al. 2006). However, a similar study carried out in the cycling monkey showed a decrease of plasma SP concentrations during the follicular phase leading to the LH surge and an inverse relationship between SP and estradiol values during this time (Kerdelhue et al. 2000). Thus, there appears to be a dual role for SP regarding the LH surge mechanism, as there have been inhibitory and stimulatory effects reported depending on species, sex steroid concentrations as well as the timing of exposure relative to the $\mathrm{LH}$ surge onset. The mechanism by which SP plays a role in the events leading up to the LH surge is not clear; however, the fact that $25 \%$ of Kiss 1 neurons in the AVPV/PeN contain Tac1r provides some input on the potential involvement of SP in this process (Navarro et al. 2015). In support of this notion is the observation that SP stimulates $\mathrm{LH}$ to a greater extent in female compared to male mice (Navarro et al. 2015), which are devoid of an AVPV/PeV Kiss1 population (Clarkson \& Herbison 2006, Kauffman et al. 2007).

Precedent studies on the role of SP have also reported a potential action of SP on sexual behavior. The circuitry necessary for the expression of female sexual behavior, and specifically the estrogen-induced display of lordosis, originates from the ventro-lateral $\mathrm{VMN}(\mathrm{vl} \mathrm{VMN})$ and projects to the midbrain periaqueductal central gray (Pfaff \& Sakuma 1979, Muntz et al. 1980, Yamanouchi et al. 1990). A number of studies have suggested that SP may be an important participant in this circuitry, as SP injections in the periaqueductal central gray of OVX, estrogen-primed rats produced a long-lasting increase of lordosis behavior (Dornan et al. 1987), whereas SP antiserum injections in the same region inhibit the behavior (Dornan et al. 1987). Interestingly, FluoroGold injections into the dorsal midbrain labeled a large proportion (approximately 30\%) of the vI VMN neurons immunoreactive for SP in the guinea pig (Ricciardi \& Blaustein 1994). Furthermore, pulsatile administration of estradiol selectively induces the expression of progesterone receptors in SP neurons located in this area (Olster \& Blaustein 1992), and this process is necessary for the induction of lordosis (Rubin \& Barfield 1983). Collectively, these results suggest that SP originating in the $\mathrm{VI} \mathrm{VMN}$ may participate in the onset of lordosis behavior (Dornan et al. 1990), however, further detailed components of the anatomy and physiology of this neurocircuitry is missing.

\section{Neurokinin A}

By contrast, much less information is available on the other members of the tachykinin family such as NKA or its two elongated peptides, NPK and NP $\gamma$. NKA is also encoded by the Tac1 gene in the rodent and preferentially binds to the NK2R (Beaujouan et al. 2000). The NKA/ NK2R signaling system appears to act through different regulatory mechanisms, than those identified for SP; however, it is noteworthy that results to date have been a lot more consistent across species (Table 3). Central administration of the NK2R agonist, GR64349, displayed a NKB-like action in terms of $\mathrm{LH}$ release (the so called dual effect of senktide), showing inhibition in OVX mice but clear stimulation in $\mathrm{OVX}+\mathrm{E}_{2}$-treated female and intact male mice (Navarro et al. 2015). However, this

Table 3 Summary of results from in vivo studies investigating the effects of Neurokinin A on LH secretion in various species.

\begin{tabular}{|c|c|c|c|c|c|c|c|}
\hline Species & Sex & Age & Drug & Gonadal status & Route & LH & Reference \\
\hline \multicolumn{8}{|c|}{ With the presence of sex steroids } \\
\hline Rat & Male & Adult & NKA peptide & Intact & i.c.v. & Stimulation & Kalra et al. (1992) \\
\hline Mouse & Male & Adult & GR64349 (NK2R-Agonist) & Intact & i.c.v. & Stimulation & Navarro et al. (2015) \\
\hline Mouse & Female & Adult & GR64349 (NK2R-Agonist) & $\mathrm{OVX}+\mathrm{E}_{2}$ & i.c.v. & Stimulation & Navarro et al. (2015) \\
\hline Rat & Female & Adult & GR64349 (NK2R-Agonist) & Intact & i.c.v. & No effect & Ruiz-Pino et al. (2015) \\
\hline Rat & Male & Adult & GR64349 (NK2R-Agonist) & Intact & i.c.v. & Stimulation & Ruiz-Pino et al. (2015) \\
\hline \multicolumn{8}{|c|}{ Without the presence of sex steroids } \\
\hline Rat & Male & Adult & NKA peptide & Castrated & i.c.v. & Inhibition & Kalra et al. (1992) \\
\hline Rat & Female & Adult & NKA peptide & OVX & i.c.v. & No effect & Sahu and Kalra (1992) \\
\hline Rat & Female & Adult & (Nle10)NKA 4-10 (NK2R-Agonist) & OvX & i.c.v. & Inhibition & Sahu and Kalra (1992) \\
\hline Mouse & Female & Adult & GR64349 (NK2R-Agonist) & OVX & i.c.v. & Inhibition & Navarro et al. (2015) \\
\hline \multicolumn{8}{|c|}{ Prepubertally } \\
\hline Rat & Female & Prepubertal & GR64349 (NK2R-Agonist) & Intact & i.c.v. & Stimulation & Ruiz-Pino et al. (2015) \\
\hline Rat & Male & Prepubertal & GR64349 (NK2R-Agonist) & Intact & i.c.v. & Stimulation & Ruiz-Pino et al. (2015) \\
\hline
\end{tabular}

OVX, ovariectomized female; OVX $+\mathrm{E}_{2}$, ovariectomized and estradiol treated female. 
stimulation does not take place in ovary-intact female rats (Ruiz-Pino et al. 2015), suggesting the existence of species differences. Overall, these data indicate that NK2R and NK3R may converge on a common pathway to regulate $\mathrm{GnRH}$ release in a sex-independent but sex steroid-dependent manner making them ideal candidates to participate in the GnRH pulse generator (Table 3). In this aspect, pharmacological studies in goats (Yamamura et al. 2015) and sheep (Fergani et al. 2016). showed that the three NKR agonists possess the ability to induce MUA volleys and an increase in LH respectively, albeit, with a significant difference in the efficacy to do so, as much higher concentrations of NK1R and NK2R agonists were required to have a similar effect as NKB agonist or senktide respectively (Fergani et al. 2016, Yamamura et al. 2015). Therefore, a reasonable hypothesis could be that NKA (and potentially SP) participates in the pulse generator by amplifying the actions of NKB. However, this requires further investigation as equivalent pulse studies are lacking in other species. Similar to what was previously suggested for the inhibitory action of NKB, the inhibitory action of NKA on LH release appears to also be opioid mediated, at least in the rat (Kalra et al. 1992). It is plausible to speculate that there is a sex steroiddependent differential activation of the stimulatory (NK3R) or inhibitory receptor (KOR) after the administration of an NKA agonist in the presence vs absence of sex steroids; however, this remains to be proven.

\section{Tachykinins modulate the gonadotropic axis in a kisspeptin-dependent manner}

It is now well recognized that the stimulating effects of NKB on GnRH secretion are mediated primarily via initial kisspeptin stimulation. This has been demonstrated by studies that have shown that (a) desensitization of the kisspeptin receptor blocks the stimulatory effect of senktide in monkeys (Ramaswamy et al. 2011), (b) senktide i.c.v. administration induces C-Fos activation of kisspeptin cells in the ARC of rats (Navarro et al. 2011a), (c) as mentioned previously, nearly all ARC kisspeptin cells contain NK3R receptors (Navarro et al. 2009) and are excited by senktide/NKB (de Croft et al. 2013), (d) the stimulatory effect of senktide is completely absent in Kiss1rKO mice (Garcia-Galiano et al. 2012) and (e) specific ablation of NK3R expressing neurons in the ARC of the rat impairs the postcastration rise in $\mathrm{LH}$ secretion (Mittelman-Smith et al. 2012). The previously mentioned studies clearly indicate the importance of NKB signaling on kisspeptin for GnRH stimulation. However, additional regulation of $\mathrm{GnRH}$ release at a different level, i.e. kisspeptin-independent action, cannot be excluded given the presence of NK1R and NK3R in a subset of GnRH neurons (Krajewski et al. 2005, Navarro et al. 2015) and the reported kisspeptinindependent activation of $\mathrm{GnRH}$ neurons by NK3R agonists in vitro (Gaskins et al. 2013).
In this regard, a similar mechanism of action appears to be used by SP and NKA. Recent electrophysiological studies in a kisspeptin-green fluorescent protein mouse model have described potent stimulatory actions of SP and NKA on ARC Kiss1 neurons (de Croft et al. 2013). In addition, the administration of all individual tachykinin receptor agonists to mice lacking Kiss1r (Kiss 1rKO mice) resulted in absent LH responses (Navarro et al. 2015). This, taken together with the fact that $50 \%$ of KNDy neurons contain NK1R (Navarro et al. 2015), suggests that SP is able to stimulate LH secretion by acting, at least in part, via a kisspeptin-dependent mechanism (Fig. 1). Intriguingly, in a recent study on female mice, NK1R agonist (GR73632) elicited a greater LH response than that observed with an NK2R agonist (GR64349; (Navarro et al. 2015)). It is possible that the augmented stimulatory action of NK1R agonist on $\mathrm{LH}$ release is a reflection of the additional action of SP on both populations of Kiss1 neurons (ARC and AVPV/PeN) (Navarro et al. 2015). In support of this hypothesis, the same exaggerated effect of NK1R agonist was not observed in male mice (Navarro et al. 2015), which also lack an AVPV kiss1 neuronal population (Smith et al. 2005, Kauffman et al. 2007). Potential direct action on $\mathrm{GnRH}$ neurons, however, cannot be overlooked, as at least in the mouse, a subset of GnRH neurons express SP (and NKB) receptors (Navarro et al. 2015) and senktide can induce in vitro $\mathrm{GnRH}$ secretion in the ME in brain slices derived from Kiss 1-knockout mice (Gaskins et al. 2013). In this light, a very important question arises, which is also true for the action of NKB, as to which pathway is used when (kisspeptin vs GnRH dependent pathways) and for what biological purpose. Potentially, as the majority of studies investigating the necessity of an intact Kiss1/Kiss1 $\mathrm{r}$ signaling system in the stimulation of LH secretion by tachykinins have been carried out in the persistent hypogonadal state (primarily via the blockade of kiss1r; see above), it is plausible to speculate that the sex steroid milieu may be an important determining factor. Studies carried out with or without the presence of sex steroids and an absent Kiss1/Kiss1r system may be useful in this aspect. The action of NKA, however, is less clear, because Tacr2 is not present in either Kiss1 or GnRH neurons, while showing a kisspeptindependent action (Navarro et al. 2015), thus suggesting the presence of unidentified intermediate neurons upstream of Kiss1 neurons. Nonetheless, even though there are still major gaps in our knowledge regarding the potential mechanisms used by each tachykinin, current data are overall, placing tachykinins in the spotlight as prime candidates for the neuromodulation of kisspeptin release.

Despite substantial evidence for the hypothalamic action of tachykinins, we cannot ignore observations that suggest a direct action of SP and NKA in the pituitary. Firstly, SP fibers have been observed to surround hypophyseal portal blood capillary vessels in the ME in 
monkeys (Kalil et al. 2015) and NKRs have been shown to exist in pituitary cells in rats (Larsen et al. 1992) and sheep (Dupre et al. 2010). Second, it has been reported that SP and NKA can stimulate $\mathrm{LH}$ secretion from cultured anterior pituitary cells derived from intact male rats (Kalra et al. 1992) and hemi-pituitaries (Shamgochian \& Leeman 1992) respectively. Furthermore, in the pig, this has been shown to be a result of direct action upon gonadotropes (Hidalgo-Díaz et al. 1998), and depends on extracellular and intracellular $\mathrm{Ca}_{2}{ }^{+}$levels, but does not involve net increases in LH $\beta$ mRNA levels (HidalgoDíaz et al. 2003). These findings, however, are not consistent as the same was not observed in dispersed anterior pituitary cells harvested from female OVX $+\mathrm{E}_{2}$ rats (Arisawa et al. 1990). Clearly, this pathway of action requires further investigation. For example, it would be interesting to evaluate whether $\mathrm{LH}$ secretion is stimulated after the peripheral administration of NKR agonists, but in the presence of a GnRH antagonist, to rule out any central effects on, or above, GnRH neurons that these agonists might exert by crossing the blood-brain barrier. This approach could potentially shed more light on the likelihood of a pituitary action of tachykinins.

\section{The role of tachykinins on puberty onset}

The precise neuronal and endocrine mechanisms that determine the timing of puberty onset, and the subsequent achievement of reproductive capacity, remains one of the greatest unanswered questions in reproductive biology. To date, several factors from central and peripheral origins have been described to regulate the awakening of the gonadotropic axis (Ojeda \& Lomniczi 2014). At a neuroendocrine level, the prevailing view is that during the infantile and juvenile periods, neurons secreting $\mathrm{GnRH}$ are subjected to persistent synaptic inhibition (Ojeda et al. 2010). When this inhibition is removed, GnRH secretion increases, which leads to puberty. However, it is recognized that a gain in numerous excitatory inputs to $\mathrm{GnRH}$ neurons is also indispensable (Ojeda \& Lomniczi 2014). In this respect, both loss-offunction and gain-of-function mutations in a growing number of neurotransmitters, and their receptors have been described to severely impinge on the pubertal transition. As mentioned previously, a number of studies have documented lack or delay of pubertal maturation in humans and mice bearing loss-of-function mutations in KISS1/KISS1R or TAC3/TACR3 genes (de Roux et al. 2003, Seminara et al. 2003, Young et al. 2010, Topaloglu et al. 2012). In contrast, gain-of-function mutations in KISS1R have been identified in association with central precocious puberty (Teles et al. 2008). Therefore, kisspeptins are indispensable regulatory signals of GnRH release during puberty (Seminara et al. 2003). In the same vein, the tachykinin NKB has been reported to stimulate kisspeptin prepubertally (Navarro et al. 2012) and the expression of Tac2 increases before Kiss 1
(Gill et al. 2012), suggesting a likely role of this tachykinin in the pubertal activation of kisspeptin-GnRH secretion (Topaloglu et al. 2009, Young et al. 2010).

The equivalent role of SP and NKA in the prepubertal increase of LH release and their contribution to the timing of puberty onset has only recently began to draw attention. A series of functional tests and genetic studies in the female mouse have shown that SP/NK1R and NKA/NK2R signaling appears to participate in the timing of puberty. This conclusion is derived from a study by Simavli and coworkers (2015), which has shown that (1) a selective NK1R agonist induces LH release in prepubertal females; (2) the expression of Tac1 and Tacr 1 in the ARC is increased just before puberty compared with earlier or later stages of postnatal development; (3) repeated exposure to NK1R agonists prepubertally advances puberty onset, suggesting that the NK1R is already present and functional during this developmental period. Furthermore, (4) Tac1KO female mice exhibit a significant delay in vaginal opening (defined as complete canalization of the vagina, an event that occurs with increased estrogen secretion (Caligioni 2009) and is therefore considered an indirect maker for puberty onset) and delayed initiation of estrous cyclicity (Simavli et al. 2015). This suggests that although $E_{2}$ is produced by the ovaries in these mice, this alone may not be sufficient to trigger an LH surge during the initial phase post-vaginal opening, and this positive feedback may also be compromised during adulthood. Indeed, histological examination of the ovaries revealed fewer numbers of corpus lutea and antral follicles in Tac1knockout mice. Similarly, in the rat, administration of NK1R and NK2R agonists was able to significantly increase $\mathrm{LH}$ release in prepubertal animals of both sexes, with NK2R agonist evoking a significantly greater response than that by NK1R agonist in both males and females (Ruiz-Pino et al. 2015). By contrast, castrated, juvenile and $\mathrm{GnRH}$ primed monkeys did not respond to an i.v. bolus administration of SP with an increase in LH secretion (Kalil et al. 2015). The reason for this is not known; however, it may reflect a species difference. Interestingly, supporting the role of SP in the central control of puberty onset is the fact that higher SP levels detected in the brain of patients after traumatic brain injury (Vink \& van den Heuvel 2010, Zacest et al. 2010, Gabrielian et al. 2013) correlate with the significantly higher ratio of children displaying precocious puberty after traumatic brain injury (Blendonohy \& Philip 1991, Kaulfers et al. 2010). Overall, these data suggest a greater sensitivity to hypothalamic SP (and possibly NKA), at the time of puberty initiation, presumably contributing to an increase in GnRH pulses and activation of the gonadotropic axis; however, despite the compelling evidence for a central role of SP, we cannot rule out the possibility of actions of SP in other organs of the gonadotropic axis, such as the ovary (Debeljuk 2003, 2006). 


\section{Concluding remarks}

Elucidating the neuronal mechanisms generating the $\mathrm{GnRH}$ pulses and surge is a prerequisite in advancing our understanding of reproductive function. This review intends to discuss the existing literature on the role of tachykinins as important components of this mechanism leading to $\mathrm{GnRH}$ and, therefore, $\mathrm{LH}$ secretion (model hypothesis; Fig. 1). Overall, substantial evidence exists to support the hypothesis that tachykinins are indeed involved in the control of $\mathrm{GnRH}$ release, by modulating the firing of ARC KNDy neurons either directly (NKB and SP) or indirectly (NKA) to shape kisspeptin pulses (Fig. 1). In addition, tachykinins, particularly SP may also act directly on GnRH and/or AVPV/PeN Kiss1 neurons to contribute to: (a) the shaping of $\mathrm{GnRH}$ pulses, and/ or (b) the generation of the preovulatory LH surge. Many aspects of the physiology of the SP/NK1R, NKA/ NK2R signaling systems in the context of reproduction, remain to be fully characterized. For instance, there appears to be a relative inconsistency in results between mice, rats, ruminants and monkeys in the $\mathrm{LH}$ response to the administration of tachykinins that may reflect anatomical and functional differences among species. In this regard, in humans SP is colocalized within a subset of KNDy neurons (Hrabovszky et al. 2013), whereas this is not true for all other species studied to date (Rance \& Young 1991, Rance \& Bruce 1994, Kalil et al. 2015, Navarro et al. 2015). Furthermore, in ruminants, a much larger dose of SP is required to stimulate $\mathrm{LH}$ release to a similar magnitude as an NKB agonist (Fergani et al. 2016, Yamamura et al. 2015), whereas in mice, similar doses of all individual NKR agonists can lead to an increase in LH (Navarro et al. 2015). However, as discussed, routes of administration, age (prepubertal vs postpubertal) and sex steroid status might be a determining factor in this aspect and must be taken in to account. Another important parameter that requires specific attention in future studies is the considerable cross-reactivity that exists between these receptor/ ligand systems determining the efficacy of tachykinin administration and it may be that although the three NKRs are involved in the GnRH pulse generation of KNDy neurons, the ratio of the contribution of each NKR varies among species and/or sexes. Nonetheless, this phenomenon may offer important advantages in the treatment of disorders caused by disruption of one specific system. For example, the reversal phenotype in reproductive viability observed in individuals with TAC3/ TACR3 mutations (Gianetti et al. 2010) may be due to compensation by the other tachykinin systems although this remains to be elucidated. Altogether, there is a clear need for a deeper understanding of the mechanism of action of tachykinins. We must answer: (a) whether all tachykinins participate in the generation of LH pulses, (b) if there is compensation between tachykinins to exert this role and to what extent, (c) whether the pathway
(KNDy vs $\mathrm{GnRH}$ ) of tachykinin action is governed by sex steroid levels and the biological role of this interaction, (d) if the expression of tachykinin receptors in GnRH neurons changes (increases or decreases) in an estradiol dependent manner, (e) the anatomical relationship of tachykinins and their receptors with kisspeptin and $\mathrm{GnRH}$ perikarya and fibers in other species, apart from the mouse, $(f)$ the sex and species differences in the response to tachykinins and the contribution of SP/ NK1R signaling on AVPV/PeN Kiss1 neurons or GnRH for the occurrence of the GnRH/LH surge in the female, (h) the mechanism and site of action of NKA, as well as the phenotype of the cells that contain NK2R, which appear to be surrogates for the indirect action of Tac1 on KNDy neurons.

All of these unresolved questions are fundamental to the understanding the mechanisms that govern $\mathrm{GnRH}$ release in mammals, and the outcome of studies such as these may prompt a change in the thinking of the current models of GnRH pulse generation. Moreover, expanding the current model will have tremendous clinical potential in humans as there is a large number of disorders associated with dysregulation of $\mathrm{GnRH}$ release, e.g. delayed and precocious puberty, polycystic ovarian syndrome, hormone-dependent tumors, that could be treated in a more physiological and effective manner.

\section{Declaration of interest}

The authors declare that there is no conflict of interest that could be perceived as prejudicing the impartiality of this review.

\section{Funding}

This research did not receive any specific grant from any funding agency in the public, commercial or not-for-profit sector.

\section{Acknowledgements}

This work was supported by the Eunice Kennedy Shriver National Institute of Child Health and Human Development grant R00 HD071970.

\section{References}

Ahn T, Fergani C, Coolen LM, Padmanabhan V \& Lehman MN 2015 Prenatal testosterone excess decreases neurokinin 3 receptor immunoreactivity within the arcuate nucleus KNDy cell population. Journal of Neuroendocrinology 27 100-110. (doi:10.1111/jne.12244)

Akesson TR \& Micevych PE 1988 Estrogen concentration by substance P-immunoreactive neurons in the medial basal hypothalamus of the female rat. Journal of Neuroscience Research 19 412-419, 470-471. (doi:10.1002/jnr.490190405)

Amstalden M, Coolen LM, Hemmerle AM, Billings HJ, Connors JM, Goodman RL \& Lehman MN 2010 Neurokinin 3 receptor immunoreactivity in the septal region, preoptic area and hypothalamus 
of the female sheep: colocalisation in neurokinin B cells of the arcuate nucleus but not in gonadotrophin-releasing hormone neurones. Journal of Neuroendocrinology 22 1-12. (doi:10.1111/j.13652826.2009.01930.x)

Arisawa M, De Palatis L, Ho R, Snyder GD, Yu WH, Pan G \& McCann SM 1990 Stimulatory role of substance P on gonadotropin release in ovariectomized rats. Neuroendocrinology 51 523-529. (doi:10.1159/000125386)

Beaujouan JC, Saffroy M, Torrens Y \& Glowinski J 2000 Different subtypes of tachykinin NK(1) receptor binding sites are present in the rat brain. Journal of Neurochemistry 75 1015-1026. (doi:10.1046/j.14714159.2000.0751015.x)

Billings HJ, Connors JM, Altman SN, Hileman SM, Holaskova I, Lehman MN, McManus CJ, Nestor CC, Jacobs BH \& Goodman RL 2010 Neurokinin B acts via the neurokinin-3 receptor in the retrochiasmatic area to stimulate luteinizing hormone secretion in sheep. Endocrinology 151 3836-3846. (doi:10.1210/en.2010-0174)

Blendonohy PM \& Philip PA 1991 Precocious puberty in children after traumatic brain injury. Brain Injury $\mathbf{5}$ 63-68. (doi:10.3109/02699059108998513)

Borsay BA, Skrapits K, Herczeg L, Ciofi P, Bloom SR, Ghatei MA Dhillo WS, Liposits Z \& Hrabovszky E 2014 Hypophysiotropic gonadotropin-releasing hormone projections are exposed to dense plexuses of kisspeptin, neurokinin B and substance $\mathrm{p}$ immunoreactive fibers in the human: a study on tissues from postmenopausal women. Neuroendocrinology 100 141-152. (doi:10.1159/000368362)

Caligioni CS 2009 Assessing reproductive status/stages in mice. Current Protocols in NeuroscienceAppendix $\mathbf{4}$ Appendix 4l. (doi:10.1002/0471142301.nsa04is48)

Cascieri MA, Huang RR, Fong TM, Cheung AH, Sadowski S, Ber E \& Strader CD 1992 Determination of the amino acid residues in substance $\mathrm{P}$ conferring selectivity and specificity for the rat neurokinin receptors. Molecular Pharmacology 41 1096-1099.

Chan YM, Broder-Fingert S, Paraschos S, Lapatto R, Au M, Hughes V, Bianco SD, Min L, Plummer L, Cerrato F et al. $2011 \mathrm{GnRH}$-deficient phenotypes in humans and mice with heterozygous variants in KISS1/Kiss1. Journal of Clinical Endocrinology and Metabolism 96 E1771-E1781. (doi:10.1210/jc.2011-0518)

Cheng G, Coolen LM, Padmanabhan V, Goodman RL \& Lehman MN 2010 The kisspeptin/neurokinin B/dynorphin (KNDy) cell population of the arcuate nucleus: sex differences and effects of prenatal testosterone in sheep. Endocrinology 151 301-311. (doi:10.1210/en.2009-0541)

Clarkson J \& Herbison AE 2006 Postnatal development of kisspeptin neurons in mouse hypothalamus; sexual dimorphism and projections to gonadotropin-releasing hormone neurons. Endocrinology 147 5817-5825. (doi:10.1210/en.2006-0787)

Clarkson I, d'Anglemont de Tassigny $\mathrm{X}$, Colledge WH, Caraty A \& Herbison AE 2009 Distribution of kisspeptin neurones in the adult female mouse brain. Journal of Neuroendocrinology 21 673-682. (doi:10.1111/j.1365-2826.2009.01892.x)

Coiro V, Volpi R, Capretti L, Caiazza A, Marcato A, Bocchi R, Colla R, Rossi G \& Chiodera P 1992 Luteinizing hormone response to an intravenous infusion of substance $\mathrm{P}$ in normal men. Metabolism 41 689-691. (doi:10.1016/0026-0495(92)90305-T)

de Croft S, Boehm U \& Herbison AE 2013 Neurokinin B activates arcuate kisspeptin neurons through multiple tachykinin receptors in the male mouse. Endocrinology 154 2750-2760. (doi:10.1210/en.2013-1231)

De Felipe C, Herrero JF, O'Brien JA, Palmer JA, Doyle CA, Smith AJ, Laird JM, Belmonte C, Cervero F \& Hunt SP 1998 Altered nociception, analgesia and aggression in mice lacking the receptor for substance $\mathrm{P}$. Nature 392 394-397. (doi:10.1038/32904)

de Roux N, Genin E, Carel JC, Matsuda F, Chaussain JL \& Milgrom E 2003 Hypogonadotropic hypogonadism due to loss of function of the KiSS1-derived peptide receptor GPR54. PNAS 100 10972-10976. (doi:10.1073/pnas.1834399100)

Debeljuk L 2003 Tachykinins in the normal and gonadotropin-stimulated ovary of the mouse. Peptides 24 1445-1448. (doi:10.1016/j. peptides.2003.09.009)

Debeljuk L 2006 Tachykinins and ovarian function in mammals. Peptides 27 736-742. (doi:10.1016/j.peptides.2005.08.002)

Dornan WA, Malsbury CW \& Penney RB 1987 Facilitation of lordosis by injection of substance $\mathrm{P}$ into the midbrain central gray. Neuroendocrinology 45 498-506. (doi:10.1159/000124781)
Dornan WA, Akesson TR \& Micevych PE 1990 A substance P projection from the $\mathrm{VMH}$ to the dorsal midbrain central gray: implication for lordosis. Brain Research Bulletin 25 791-796. (doi:10.1016/03619230(90)90061-4)

Dobson H, Ghuman S, Prabhakar S \& Smith R 2003 A conceptual model of the influence of stress on female reproduction. Reproduction 125 151-163. (doi:10.1530/rep.0.1250151)

Dupre SM, Miedzinska K, Duval CV, Yu L, Goodman RL, Lincoln GA, Davis JR, McNeilly AS, Burt DD \& Loudon AS 2010 Identification of Eya3 and TAC 1 as long-day signals in the sheep pituitary. Current Biology 20 829-835. (doi:10.1016/j.cub.2010.02.066)

Duval P, Lenoir V, Garret C \& Kerdelhue B 1996 Reduction of the amplitude of preovulatory $\mathrm{LH}$ and FSH surges and of the amplitude of the in vitro $\mathrm{GnRH}$-induced LH release by substance P. Reversal of the effect by RP 67580. Neuropharmacology 35 1805-1810. (doi:10.1016/ S0028-3908(96)00124-4)

Ebner K \& Singewald N 2006 The role of substance P in stress and anxiety responses. Amino Acids 31 251-272. (doi:10.1007/s00726-006-0335-9)

Fergani C, Mazzella L, Coolen LM, McCosh RB, Hardy SL, Newcomb N, Grachev P, Lehman MN \& Goodman RL 2016 Do Substance P and Neurokinin A Play Important Roles in the Control of LH Secretion in Ewes? Endocrinology In press. (doi:10.1210/en.2016-1565)

Fraser GL, Hoveyda HR, Clarke IJ, Ramaswamy S, Plant TM, Rose C \& Millar RP 2015 The NK3 receptor antagonist ESN364 interrupts pulsatile LH secretion and moderates levels of ovarian hormones throughout the menstrual cycle. Endocrinology 156 4214-4225. (doi:10.1210/en.20151409)

Fraser GL, Ramael S, Hoveyda HR, Gheyle L \& Combalbert J 2016 The NK3 receptor antagonist ESN364 suppresses sex hormones in men and women. Journal of Clinical Endocrinology and Metabolism 101 417-426. (doi:10.1210/jc.2015-3621)

Gabrielian L, Helps SC, Thornton E, Turner RJ, Leonard AV \& Vink R 2013 Substance $\mathrm{P}$ antagonists as a novel intervention for brain edema and raised intracranial pressure. Acta Neurochirurgica Supplement 118 201-204. (doi:10.1007/978-3-7091-1434-6_37)

Garcia-Galiano D, van Ingen Schenau D, Leon S, Krajnc-Franken MA, Manfredi-Lozano M, Romero-Ruiz A, Navarro VM, Gaytan F, van Noort PI, Pinilla L et al. 2012 Kisspeptin signaling is indispensable for neurokinin B, but not glutamate, stimulation of gonadotropin secretion in mice. Endocrinology 153 316-328. (doi:10.1210/en.2011-1260)

Gaskins GT, Glanowska KM \& Moenter SM 2013 Activation of neurokinin 3 receptors stimulates $\mathrm{GnRH}$ release in a location-dependent but kisspeptin-independent manner in adult mice. Endocrinology $\mathbf{1 5 4}$ 3984-3989. (doi:10.1210/en.2013-1479)

Gether U, Johansen TE \& Schwartz TW 1993 Chimeric NK1 (substance P)/ NK3 (neurokinin B) receptors. Identification of domains determining the binding specificity of tachykinin agonists. Journal of Biological Chemistry $2687893-7898$.

Gianetti E, Tusset C, Noel SD, Au MG, Dwyer AA, Hughes VA, Abreu AP, Carroll J, Trarbach E, Silveira LF et al. 2010 TAC3/TACR3 mutations reveal preferential activation of gonadotropin-releasing hormone release by neurokinin B in neonatal life followed by reversal in adulthood. Journal of Clinical Endocrinology and Metabolism 95 2857-2867. (doi:10.1210/jc.2009-2320)

Gill JC, Wang O, Kakar S, Martinelli E, Carroll RS \& Kaiser UB 2010 Reproductive hormone-dependent and -independent contributions to developmental changes in kisspeptin in $\mathrm{GnRH}$-deficient hypogonadal mice. PLOS ONE 5 e11911. (doi:10.1371/journal.pone.0011911)

Gill JC, Navarro VM, Kwong C, Noel SD, Martin C, Xu S, Clifton DK, Carroll RS, Steiner RA \& Kaiser UB 2012 Increased neurokinin B (Tac2) expression in the mouse arcuate nucleus is an early marker of pubertal onset with differential sensitivity to sex steroid-negative feedback than Kiss1. Endocrinology 153 4883-4893. (doi:10.1210/en.2012-1529)

Goodman RL, Lehman MN, Smith JT, Coolen LM, de Oliveira CV, Jafarzadehshirazi MR, Pereira A, Iqbal J, Caraty A, Ciofi P et al. 2007 Kisspeptin neurons in the arcuate nucleus of the ewe express both dynorphin A and neurokinin B. Endocrinology 148 5752-5760. (doi:10.1210/en.2007-0961)

Goodman RL, Hileman SM, Nestor CC, Porter KL, Connors JM, Hardy SL, Millar RP, Cernea M, Coolen LM \& Lehman MN 2013 Kisspeptin, neurokinin $\mathrm{B}$, and dynorphin act in the arcuate nucleus to control activity of the GnRH pulse generator in ewes. Endocrinology 154 4259-4269. (doi:10.1210/en.2013-1331) 
Goodman RL, Coolen LM \& Lehman MN 2014 A role for neurokinin B in pulsatile GnRH secretion in the ewe. Neuroendocrinology 99 18-32. (doi:10.1159/000355285)

Gottsch ML, Navarro VM, Zhao Z, Glidewell-Kenney C, Weiss J, Jameson JL, Clifton DK, Levine JE \& Steiner RA 2009 Regulation of Kiss 1 and dynorphin gene expression in the murine brain by classical and nonclassical estrogen receptor pathways. Journal of Neuroscience 29 9390-9395. (doi:10.1523/JNEUROSCI.0763-09.2009)

Goubillon ML, Forsdike RA, Robinson JE, Ciofi P, Caraty A \& Herbison AE 2000 Identification of neurokinin B-expressing neurons as an highly estrogen-receptive, sexually dimorphic cell group in the ovine arcuate nucleus. Endocrinology 141 4218-4225. (doi:10.1210/en.141.11.4218)

Grachev P, Li XF, Lin YS, Hu MH, Elsamani L, Paterson SJ, Millar RP, Lightman SL \& O'Byrne KT 2012 GPR54-dependent stimulation of luteinizing hormone secretion by neurokinin B in prepubertal rats. PLoS ONE 7 e44344. (doi:10.1371/journal.pone.0044344)

Harlan RE, Garcia MM \& Krause JE 1989 Cellular localization of substance $\mathrm{P}$ - and neurokinin A-encoding preprotachykinin mRNA in the female rat brain. Journal of Comparative Neurology 287 179-212. (doi:10.1002/ cne.902870204)

Herbison AE 1998 Multimodal influence of estrogen upon gonadotropinreleasing hormone neurons. Endocrine Reviews 19 302-330. (doi:10.1210/edrv.19.3.0332)

Herbison AE 2016 Control of puberty onset and fertility by gonadotropinreleasing hormone neurons. Nature Reviews Endocrinology 12 452-466. (doi:10.1038/nrendo.2016.70)

Herbison AE, Porteous R, Pape JR, Mora JM \& Hurst PR 2008 Gonadotropinreleasing hormone neuron requirements for puberty, ovulation, and fertility. Endocrinology 149 597-604. (doi:10.1210/en.2007-1139)

Hidalgo-Díaz C, Castaño JP, López-Pedrera R, Malagón MM, GarcíaNavarro S \& Gracia-Navarro F 1998 A modulatory role for substance P on the regulation of luteinizing hormone secretion by cultured porcine gonadotrophs. Biology of Reproduction 58 678-685. (doi:10.1095/ biolreprod58.3.678)

Hidalgo-Díaz C, Malagón MM, García-Navarro S, Luque RM, González de Aguilar JL, Gracia-Navarro F \& Castaño JP 2003 Role of Ca2+ in the secretory and biosynthetic response of porcine gonadotropes to substance $\mathrm{P}$ and gonadotropin-releasing hormone. Regulatory Peptides 116 43-52. (doi:10.1016/S0167-0115(03)00176-9)

Hrabovszky E 2014 Neuroanatomy of the human hypothalamic kisspeptin system. Neuroendocrinology 99 33-48. (doi:10.1159/000356903)

Hrabovszky E \& Liposits Z 2013 Afferent neuronal control of type-I gonadotropin releasing hormone neurons in the human. Frontiers in Endocrinology 4 130. (doi:10.3389/fendo.2013.00130)

Hrabovszky E, Borsay BA, Racz K, Herczeg L, Ciofi P, Bloom SR, Ghatei MA, Dhillo WS \& Liposits Z 2013 Substance p immunoreactivity exhibits frequent colocalization with kisspeptin and neurokinin B in the human infundibular region. PLOS ONE 8 e72369. (doi:10.1371/journal.pone.0072369)

Kalil B, Ramaswamy S \& Plant TM 2015 The distribution of substance P and kisspeptin in the mediobasal hypothalamus of the male rhesus monkey and a comparison of intravenous administration of these peptides to release $\mathrm{GnRH}$ as reflected by $\mathrm{LH}$ secretion. Neuroendocrinology 103 711-723. (doi:10.1159/000442420)

Kalra PS, Sahu A, Bonavera JJ \& Kalra SP 1992 Diverse effects of tachykinins on luteinizing hormone release in male rats: mechanism of action. Endocrinology 131 1195-1201. (doi:10.1210/en.131.3.1195)

Kauffman AS, Gottsch ML, Roa J, Byquist AC, Crown A, Clifton DK, Hoffman GE, Steiner RA \& Tena-Sempere M 2007 Sexual differentiation of Kiss1 gene expression in the brain of the rat. Endocrinology $\mathbf{1 4 8}$ 1774-1783. (doi:10.1210/en.2006-1540)

Kaulfers AM, Backeljauw PF, Reifschneider K, Blum S, Michaud L, Weiss M \& Rose SR 2010 Endocrine dysfunction following traumatic brain injury in children. Journal of Pediatrics 157 894-899. (doi:10.1016/j. jpeds.2010.07.004)

Kawakami M, Uemura T \& Hayashi R 1982 Electrophysiological correlates of pulsatile gonadotropin release in rats. Neuroendocrinology 35 63-67. (doi:10.1159/000123356)

Keen KL, Wegner FH, Bloom SR, Ghatei MA \& Terasawa E 2008 An increase in kisspeptin-54 release occurs with the pubertal increase in luteinizing hormone-releasing hormone- 1 release in the stalk-median eminence of female rhesus monkeys in vivo. Endocrinology 149 4151-4157. (doi:10.1210/en.2008-0231)
Kerdelhue B, Gordon K, Williams R, Lenoir V, Fardin V, Chevalier P, Garret C, Duval P, Kolm P, Hodgen G et al. 1997 Stimulatory effect of a specific substance $P$ antagonist (RPR 100893) of the human NK1 receptor on the estradiol-induced $\mathrm{LH}$ and FSH surges in the ovariectomized cynomolgus monkey. Journal of Neuroscience Research 50 94-103. (doi:10.1002/ (SICI)1097-4547(19971001)50:1<94::AID-JNR10>3.0.CO;2-A)

Kerdelhue B, Williams RF, Lenoir V, Fardin V, Kolm P, Hodgen GD, Jones GS, Scholler R \& Jones HW Jr 2000 Variations in plasma levels of substance $P$ and effects of a specific substance $P$ antagonist of the NK(1) receptor on preovulatory $\mathrm{LH}$ and $\mathrm{FSH}$ surges and progesterone secretion in the cycling cynomolgus monkey. Neuroendocrinology 71 228-236. (doi:10.1159/000054540)

Kerdelhue B, Lenoir V, Scholler R \& Jones HW Jr 2006 Substance P plasma concentration during the LH preovulatory surge of the menstrual cycle in the human. Neuroendocrinology Letters 27 359-364.

Kinsey-Jones JS, Grachev P, Li XF, Lin YS, Milligan SR, Lightman SL \& O'Byrne KT 2012 The inhibitory effects of neurokinin B on GnRH pulse generator frequency in the female rat. Endocrinology 153 307-315. (doi:10.1210/en.2011-1641)

Krajewski SJ, Anderson MJ, Iles-Shih L, Chen KJ, Urbanski HF \& Rance NE 2005 Morphologic evidence that neurokinin B modulates gonadotropinreleasing hormone secretion via neurokinin 3 receptors in the rat median eminence. Journal of Comparative Neurology 489 372-386. (doi:10.1002/cne.20626)

Krajewski SJ, Burke MC, Anderson MJ, McMullen NT \& Rance NE 2010 Forebrain projections of arcuate neurokinin B neurons demonstrated by anterograde tract-tracing and monosodium glutamate lesions in the rat. Neuroscience 166 680-697. (doi:10.1016/j.neuroscience.2009.12.053)

Larsen PJ, Saermark T \& Mau SE 1992 Binding of an iodinated substance $\mathrm{P}$ analogue to cultured anterior pituitary prolactin- and luteinizing hormone-containing cells. Journal of Histochemistry and Cytochemistry 40 487-493. (doi:10.1177/40.4.1372633)

Lasaga M \& Debeljuk L 2011 Tachykinins and the hypothalamo-pituitarygonadal axis: an update. Peptides 32 1972-1978. (doi:10.1016/j. peptides.2011.07.009)

Lehman MN, Coolen LM \& Goodman RL 2010 Minireview: kisspeptin/ neurokinin B/dynorphin (KNDy) cells of the arcuate nucleus: a central node in the control of gonadotropin-releasing hormone secretion. Endocrinology 151 3479-3489. (doi:10.1210/en.2010-0022)

Leon S, Barroso A, Vazquez MJ, Garcia-Galiano D, Manfredi-Lozano M, Ruiz-Pino F, Heras V, Romero-Ruiz A, Roa J, Schutz G et al. 2016 Direct actions of kisspeptins on $\mathrm{GnRH}$ neurons permit attainment of fertility but are insufficient to fully preserve gonadotropic axis activity. Scientific Reports 6 19206. (doi:10.1038/srep19206)

Luque RM, Cordoba-Chacon J, Gahete MD, Navarro VM, TenaSempere M, Kineman RD \& Castano JP 2011 Kisspeptin regulates gonadotroph and somatotroph function in nonhuman primate pituitary via common and distinct signaling mechanisms. Endocrinology 152 957-966. (doi:10.1210/en.2010-1142)

Maeda K, Adachi S, Inoue K, Ohkura S \& Tsukamura H 2007 Metastin/ kisspeptin and control of estrous cycle in rats. Reviews in Endocrine and Metabolic Disorders 8 21-29. (doi:10.1007/s11154-007-9032-6)

Maggi CA 1995 The mammalian tachykinin receptors. General Pharmacology 26 911-944. (doi:10.1016/0306-3623(94)00292-U)

Maggio JE 1988 Tachykinins. Annual Review of Neuroscience 11 13-28. (doi:10.1146/annurev.ne.11.030188.000305)

Micevych PE, Matt DW \& Go VL 1988 Concentrations of cholecystokinin, substance $P$, and bombesin in discrete regions of male and female rat brain: sex differences and estrogen effects. Experimental Neurology $\mathbf{1 0 0}$ 416-425. (doi:10.1016/0014-4886(88)90119-7)

Mittelman-Smith MA, Williams H, Krajewski-Hall SJ, Lai J, Ciofi P, McMullen NT \& Rance NE 2012 Arcuate kisspeptin/neurokinin B/ dynorphin (KNDy) neurons mediate the estrogen suppression of gonadotropin secretion and body weight. Endocrinology 1532800 2812. (doi:10.1210/en.2012-1045)

Moenter SM, DeFazio AR, Pitts GR \& Nunemaker CS 2003 Mechanisms underlying episodic gonadotropin-releasing hormone secretion. Frontiers in Neuroendocrinology 24 79-93. (doi:10.1016/S00913022(03)00013-X)

Muntz JA, Rose JD \& Shults RC 1980 Disruption of lordosis by dorsal midbrain lesions in the golden hamster. Brain Research Bulletin 5 359364. (doi:10.1016/S0361-9230(80)80005-0) 
Narayanaswamy S, Prague JK, Jayasena CN, Papadopoulou DA Mizamtsidi M, Shah AJ, Bassett P, Comninos AN, Abbara A, Bloom SR et al. 2016 Investigating the KNDy hypothesis in humans by coadministration of kisspeptin, neurokinin B, and naltrexone in men. Journal of Clinical Endocrinology and Metabolism 101 3429-3436. (doi:10.1210/jc.2016-1911)

Navarro VM 2012 New insights into the control of pulsatile GnRH release: the role of Kiss1/neurokinin B neurons. Frontiers in Endocrinology 348. (doi:10.3389/fendo.2012.00048)

Navarro VM 2013 Interactions between kisspeptins and neurokinin B. Advances in Experimental Medicine and Biology 784 325-347. (doi:10.1007/978-1-4614-6199-9_15)

Navarro VM, Castellano JM, Fernandez-Fernandez R, Barreiro ML, Roa J, Sanchez-Criado JE, Aguilar E, Dieguez C, Pinilla L \& Tena-Sempere M 2004 Developmental and hormonally regulated messenger ribonucleic acid expression of KiSS-1 and its putative receptor, GPR54, in rat hypothalamus and potent luteinizing hormone-releasing activity of KiSS1 peptide. Endocrinology 145 4565-4574. (doi:10.1210/en.2004-0413)

Navarro VM, Gottsch ML, Chavkin C, Okamura H, Clifton DK \& Steiner RA 2009 Regulation of gonadotropin-releasing hormone secretion by kisspeptin/dynorphin/neurokinin B neurons in the arcuate nucleus of the mouse. Journal of Neuroscience 29 11859-11866. (doi:10.1523/ JNEUROSCI.1569-09.2009)

Navarro VM, Castellano JM, McConkey SM, Pineda $R$, Ruiz-Pino $F_{\text {, }}$ Pinilla L, Clifton DK, Tena-Sempere M \& Steiner RA 2011a Interactions between kisspeptin and neurokinin B in the control of GnRH secretion in the female rat. American Journal of Physiology: Endocrinology and Metabolism 300 E202-E210. (doi:10.1152/ajpendo.00517.2010)

Navarro VM, Gottsch ML, Wu M, Garcia-Galiano D, Hobbs SJ, Bosch MA, Pinilla L, Clifton DK, Dearth A, Ronnekleiv OK et al. 2011b Regulation of NKB pathways and their roles in the control of Kiss1 neurons in the arcuate nucleus of the male mouse. Endocrinology 152 4265-4275. (doi:10.1210/en.2011-1143)

Navarro VM, Ruiz-Pino F, Sanchez-Garrido MA, Garcia-Galiano D, Hobbs SJ, Manfredi-Lozano M, Leon S, Sangiao-Alvarellos S, Castellano JM, Clifton DK et al. 2012 Role of neurokinin B in the control of female puberty and its modulation by metabolic status. Journal of Neuroscience 32 2388-2397. (doi:10.1523/JNEUROSCI.4288-11.2012)

Navarro VM, Bosch MA, Leon S, Simavli S, True C, Pinilla L, Carroll RS, Seminara SB, Tena-Sempere M, Ronnekleiv OK et al. 2015 The integrated hypothalamic tachykinin-kisspeptin system as a central coordinator for reproduction. Endocrinology 156 627-637. (doi:10.1210/en.20141651)

Noritake K, Matsuoka T, Ohsawa T, Shimomura K, Sanbuissho A, Uenoyama Y, Maeda K \& Tsukamura H 2011 Involvement of neurokinin receptors in the control of pulsatile luteinizing hormone secretion in rats. Journal of Reproduction and Development 57 409-415. (doi:10.1262/ jrd.11-002S)

Oakley AE, Clifton DK \& Steiner RA 2009 Kisspeptin signaling in the brain. Endocrine Reviews 30 713-743. (doi:10.1210/er.2009-0005)

Ohkura S, Takase K, Matsuyama S, Mogi K, Ichimaru T, Wakabayashi Y, Uenoyama Y, Mori Y, Steiner RA, Tsukamura H et al. 2009 Gonadotrophin-releasing hormone pulse generator activity in the hypothalamus of the goat. Journal of Neuroendocrinology 21 813-821. (doi:10.1111/j.1365-2826.2009.01909.x)

Ojeda SR \& Lomniczi A 2014 Puberty in 2013: unravelling the mystery of puberty. Nature Reviews Endocrinology 10 67-69. (doi:10.1038/ nrendo.2013.233)

Ojeda SR, Lomniczi A, Sandau U \& Matagne V 2010 New concepts on the control of the onset of puberty. Endocrine Development 17 44-51. (doi:10.1159/000262527)

Olster DH \& Blaustein JD 1992 Estradiol pulses induce progestin receptors selectively in substance P-immunoreactive neurons in the ventrolateral hypothalamus of female guinea pigs. Journal of Neurobiology $\mathbf{2 3}$ 293-301. (doi:10.1002/neu.480230308)

Otsuka M \& Yoshioka K 1993 Neurotransmitter functions of mammalian tachykinins. Physiological Reviews 73 229-308.

Page NM 2005 New challenges in the study of the mammalian tachykinins. Peptides 26 1356-1368. (doi:10.1016/j.peptides.2005.03.030)

Patacchini R \& Maggi CA 2001 Peripheral tachykinin receptors as targets for new drugs. European Journal of Pharmacology 429 13-21. (doi:10.1016/ S0014-2999(01)01301-2)
Pfaff DW \& Sakuma Y 1979 Deficit in the lordosis reflex of female rats caused by lesions in the ventromedial nucleus of the hypothalamus. Journal of Physiology 288 203-210.

Pinilla L, Aguilar E, Dieguez C, Millar RP \& Tena-Sempere M 2012 Kisspeptins and reproduction: physiological roles and regulatory mechanisms. Physiological Reviews 92 1235-1316. (doi:10.1152/physrev.00037.2010)

Plant TM, Krey LC, Moossy J, McCormack JT, Hess DL \& Knobil E 1978 The arcuate nucleus and the control of gonadotropin and prolactin secretion in the female rhesus monkey (Macaca mulatta). Endocrinology 102 52-62. (doi:10.1210/endo-102-1-52)

Porter KL, Hileman SM, Hardy SL, Nestor CC, Lehman MN \& Goodman RL 2014 Neurokinin-3 receptor activation in the retrochiasmatic area is essential for the full pre-ovulatory luteinising hormone surge in ewes. Journal of Neuroendocrinology 26 776-784. (doi:10.1111/jne.12180)

Radovick S, Levine JE \& Wolfe A 2012 Estrogenic regulation of the GnRH neuron. Frontiers in Endocrinology 3 52. (doi:10.3389/ fendo.2012.00052)

Ramaswamy S, Seminara SB, Ali B, Ciofi P, Amin NA \& Plant TM 2010 Neurokinin B stimulates GnRH release in the male monkey (Macaca mulatta) and is colocalized with kisspeptin in the arcuate nucleus. Endocrinology 151 4494-4503. (doi:10.1210/en.2010-0223)

Ramaswamy S, Seminara SB \& Plant TM 2011 Evidence from the agonadal juvenile male rhesus monkey (Macaca mulatta) for the view that the action of neurokinin B to trigger gonadotropin-releasing hormone release is upstream from the kisspeptin receptor. Neuroendocrinology 94 237-245. (doi:10.1159/000329045)

Rance NE \& Young WS 3rd1991 Hypertrophy and increased gene expression of neurons containing neurokinin-B and substance-P messenger ribonucleic acids in the hypothalami of postmenopausal women. Endocrinology 128 2239-2247. (doi:10.1210/endo-128-5-2239)

Rance NE \& Bruce TR 1994 Neurokinin B gene expression is increased in the arcuate nucleus of ovariectomized rats. Neuroendocrinology $\mathbf{6 0}$ 337-345. (doi:10.1159/000126768)

Ricciardi KH \& Blaustein JD 1994 Projections from ventrolateral hypothalamic neurons containing progestin receptor- and substance P-immunoreactivity to specific forebrain and midbrain areas in female guinea pigs. Journal of Neuroendocrinology 6 135-144. (doi:10.1111/j.1365-2826.1994.tb00564.x)

Roa J 2013 Role of GnRH neurons and their neuronal afferents as key integrators between food intake regulatory signals and the control of reproduction. International Journal of Endocrinology 2013518046. (doi:10.1155/2013/518046)

Ronnekleiv OK, Kelly MJ \& Eskay RL 1984 Distribution of immunoreactive substance $\mathrm{P}$ neurons in the hypothalamus and pituitary of the rhesus monkey. Journal of Comparative Neurology 224 51-59. (doi:10.1002/ cne.902240105)

Rubin BS \& Barfield RJ 1983 Induction of estrous behavior in ovariectomized rats by sequential replacement of estrogen and progesterone to the ventromedial hypothalamus. Neuroendocrinology 37 218-224. (doi:10.1159/000123546)

Ruiz-Pino F, Navarro VM, Bentsen AH, Garcia-Galiano D, Sanchez-Garrido MA, Ciofi P, Steiner RA, Mikkelsen JD, Pinilla L \& Tena-Sempere M 2012 Neurokinin B and the control of the gonadotropic axis in the rat: developmental changes, sexual dimorphism, and regulation by gonadal steroids. Endocrinology 153 4818-4829. (doi:10.1210/en.2012-1287)

Ruiz-Pino F, Garcia-Galiano D, Manfredi-Lozano $M$, Leon S, Sanchez-Garrido MA, Roa J, Pinilla L, Navarro VM \& Tena-Sempere M 2015 Effects and interactions of tachykinins and dynorphin on FSH and LH secretion in developing and adult rats. Endocrinology 156 576-588. (doi:10.1210/en.2014-1026)

Ruka KA, Burger LL \& Moenter SM 2016 Both estrogen and androgen modify the response to activation of neurokinin-3 and kappa-opioid receptors in arcuate kisspeptin neurons from male mice. Endocrinology 157 752-763. (doi:10.1210/en.2015-1688)

Saffroy M, Torrens Y, Glowinski J \& Beaujouan JC 2003 Autoradiographic distribution of tachykinin NK2 binding sites in the rat brain: comparison with NK1 and NK3 binding sites. Neuroscience 116 761-773. (doi:10.1016/S0306-4522(02)00748-0)

Sahu A \& Kalra SP 1992 Effects of tachykinins on luteinizing hormone release in female rats: potent inhibitory action of neuropeptide $\mathrm{K}$. Endocrinology 130 1571-1577. (doi:10.1210/en.130.3.1571) 
Sandoval-Guzman T \& Rance NE 2004 Central injection of senktide, an NK3 receptor agonist, or neuropeptide $Y$ inhibits $\mathrm{LH}$ secretion and induces different patterns of Fos expression in the rat hypothalamus. Brain Research 1026 307-312. (doi:10.1016/j.brainres.2004.08.026)

Seabrook GR, Bowery BJ \& Hill RG 1995 Pharmacology of tachykinin receptors on neurones in the ventral tegmental area of rat brain slices. European Journal of Pharmacology 273 113-119. (doi:10.1016/00142999(94)00681-V)

Seminara SB, Messager S, Chatzidaki EE, Thresher RR, Acierno JS Jr, Shagoury JK, Bo-Abbas Y, Kuohung W, Schwinof KM, Hendrick AG et al. 2003 The GPR54 gene as a regulator of puberty. New England Journal of Medicine 349 1614-1627. (doi:10.1056/NEJMoa035322)

Shamgochian MD \& Leeman SE 1992 Substance P stimulates luteinizing hormone secretion from anterior pituitary cells in culture. Endocrinology 131 871-875. (doi:10.1210/en.131.2.871)

Simavli S, Thompson IR, Maguire CA, Gill JC, Carroll RS, Wolfe A, Kaiser UB \& Navarro VM 2015 Substance p regulates puberty onset and fertility in the female mouse. Endocrinology 156 2313-2322. (doi:10.1210/en.2014-2012)

Smith JT, Dungan HM, Stoll EA, Gottsch ML, Braun RE, Eacker SM, Clifton DK \& Steiner RA 2005 Differential regulation of KiSS-1 mRNA expression by sex steroids in the brain of the male mouse. Endocrinology 146 2976-2984. (doi:10.1210/en.2005-0323)

Steiner RA \& Navarro VM 2012 Tacking toward reconciliation on Tacr3/ TACR3 mutations. Endocrinology 153 1578-1581. (doi:10.1210/ en.2012-1032)

Stephens SB, Chahal N, Munaganuru N, Parra RA \& Kauffman AS 2016 Estrogen stimulation of Kiss1 expression in the medial amygdala involves estrogen receptor alpha but not estrogen receptor beta. Endocrinology en20161431. (doi:10.1210/en.2016-1431)

Teles MG, Bianco SD, Brito VN, Trarbach EB, Kuohung W, Xu S, Seminara SB, Mendonca BB, Kaiser UB \& Latronico AC 2008 A GPR54-activating mutation in a patient with central precocious puberty. New England Journal of Medicine 358 709-715. (doi:10.1056/ NEJMoa073443)

Topaloglu AK, Reimann F, Guclu M, Yalin AS, Kotan LD, Porter KM, Serin A, Mungan NO, Cook JR, Ozbek MN et al. 2009 TAC3 and TACR3 mutations in familial hypogonadotropic hypogonadism reveal a key role for Neurokinin B in the central control of reproduction. Nature Genetics 41 354-358. (doi:10.1038/ng.306)

Topaloglu AK, Tello JA, Kotan LD, Ozbek MN, Yilmaz MB, Erdogan S, Gurbuz F, Temiz F, Millar RP \& Yuksel B 2012 Inactivating KISS1 mutation and hypogonadotropic hypogonadism. New England Journal of Medicine 366 629-635. (doi:10.1056/NEJMoa1111184)

Traczyk WZ, Pau KY, Kaynard AH \& Spies HG 1992 Modulatory role of substance $\mathrm{P}$ on gonadotropin and prolactin secretion in the rabbit. Journal of Physiology and Pharmacology 43 279-297.

True C, Nasrin Alam S, Cox K, Chan YM \& Seminara S 2015 Neurokinin $\mathrm{B}$ is critical for normal timing of sexual maturation but dispensable for adult reproductive function in female mice. Endocrinology en 20141862. (doi:10.1210/en.2014-1862)

Tsuruo Y, Hisano S, Nakanishi J, Katoh S \& Daikoku S 1987 Immunohistochemical studies on the roles of substance $\mathrm{P}$ in the rat hypothalamus: possible implication in the hypothalamic-hypophysialgonadal axis. Neuroendocrinology 45 389-401. (doi:10.1159/000124764) Tsuruo Y, Kawano H, Hisano S, Kagotani Y, Daikoku S, Zhang T \& Yanaihara N 1991 Substance P-containing neurons innervating LHRHcontaining neurons in the septo-preoptic area of rats. Neuroendocrinology 53 236-245. (doi:10.1159/000125724)

Vink R \& van den Heuvel C 2010 Substance P antagonists as a therapeutic approach to improving outcome following traumatic brain injury. Neurotherapeutics 7 74-80. (doi:10.1016/j.nurt.2009.10.018)

Wakabayashi Y, Nakada T, Murata K, Ohkura S, Mogi K, Navarro VM, Clifton DK, Mori Y, Tsukamura H, Maeda K et al. 2010 Neurokinin B and dynorphin $\mathrm{A}$ in kisspeptin neurons of the arcuate nucleus participate in generation of periodic oscillation of neural activity driving pulsatile gonadotropin-releasing hormone secretion in the goat. Journal of Neuroscience 30 3124-3132. (doi:10.1523/JNEUROSCI.5848-09.2010)

Weems PW, Witty CF, Amstalden M, Coolen LM, Goodman RL \& Lehman MN 2016 kappa-Opioid receptor is colocalized in GnRH and KNDy cells in the female ovine and rat brain. Endocrinology $1572367-$ 2379. (doi:10.1210/en.2015-1763)

Yamamura T, Wakabayashi Y, Ohkura S, Navarro VM \& Okamura H 2015 Effects of intravenous administration of neurokinin receptor subtype-selective agonists on gonadotropin-releasing hormone pulse generator activity and luteinizing hormone secretion in goats. Journal of Reproduction and Development 61 20-29. (doi:10.1262/jrd.2014-109)

Yamano M, Inagaki S, Kito S \& Tohyama M 1986 A substance P-containing pathway from the hypothalamic ventromedial nucleus to the medial preoptic area of the rat: an immunohistochemical analysis. Neuroscience 18 395-402. (doi:10.1016/0306-4522(86)90161-2)

Yamanouchi K, Nakano Y \& Arai Y 1990 Roles of the pontine dorsomedial tegmentum and midbrain central gray in regulating female rat sexual behaviors: effects of p-chlorophenylalanine. Brain Research Bulletin 25 381-385. (doi:10.1016/0361-9230(90)90223-M)

Yang JJ, Caligioni CS, Chan YM \& Seminara SB 2012 Uncovering novel reproductive defects in neurokinin $B$ receptor null mice: closing the gap between mice and men. Endocrinology 153 1498-1508. (doi:10.1210/ en.2011-1949)

Young J, Bouligand J, Francou B, Raffin-Sanson ML, Gaillez S, Jeanpierre M, Grynberg M, Kamenicky P, Chanson P, Brailly-Tabard S et al. 2010 TAC3 and TACR3 defects cause hypothalamic congenital hypogonadotropic hypogonadism in humans. Journal of Clinical Endocrinology and Metabolism 95 2287-2295. (doi:10.1210/jc.2009-2600)

Zacest AC, Vink R, Manavis J, Sarvestani GT \& Blumbergs PC 2010 Substance $P$ immunoreactivity increases following human traumatic brain injury. Acta Neurochirurgica Supplement 106 211-216. (doi:10.1007/978-3-211-98811-4_39)

Received 25 July 2016

First decision 24 August 2016

Revised manuscript received 5 October 2016

Accepted 17 October 2016 